\title{
The Severity of Anti Hadith Groups (AHG) Thought: Solutions, Challenges and Barriers
}

\author{
Mohd Al'lkhsan Ghazali \\ Faculty of Islamic Civilization, University Technology Malaysia
}

Siti Salwa Md. Sawari

Faculty of Islamic Civilization, University Technology Malaysia

\section{Muhammad Fathi Yusuf}

Faculty of Islamic Civilization, University Technology Malaysia

\section{Doi:10.5901/mjss.2015.v6n3s2p127}

\section{Abstract}

The spread of anti-Hadith thoughts in Malaysia until nowadays is worrisome. It has spread in many sectors in our country. Educational sector is one of the sectors that has been affected by this movement. Muslims should realize that these thoughts will eventually create chaos to Muslim community and finally destroy the religion itself. The anti-Hadith groups have successfully trained cadres among Muslim scholars in an effort to realize their dreams. In order to maintain the purity of Islam, this worrisome and unsettling problem must be overcome. It is necessary to abolish the thoughts of anti-Hadith. Therefore, this study aims to identify the solutions for this problem and propose these measures to various parties who are responsible for this matter. This study also seeks to identify the problems in dealing with anti-Hadith movements. Methods such as library research and interviews have been used throughout this study to solve the problem. Researchers have found various measures to overcome the problem created by anti-Hadith groups which have been implemented by the authorities and societies themselves. However, various challenges have been encountered as anti-Hadith groups were supported by specific intellectual and influential parties. Apart from that, their secret movements and limited punishment that could be implemented also contributed to the failure of eradication of these groups. In this regard, cooperation from all parties is essential so that we can continue to strengthen the purity of Islam.

Keywords: Anti-Hadith Group; Solutions; Challenges; Hadith.

\section{Introduction}

Muslims have to realize that there are movements which have tried to destroy and eliminate Islam as a whole. They have successfully trained cadres among Muslim scholars in their efforts to realize their dreams. The most prominent movement in this century is called anti-Hadith movement. In order to maintain the purity of Islam, the anti-Hadith movement should be abolished. Although some have said that the issue is very sensitive to discuss, it is necessary to eliminate this movement as it is related to Muslims' faith. Furthermore, the anti-Hadith groups are actively spreading their beliefs and thoughts. If Muslims are not sensitive about this issue, many of them will be affected by this movement (Ghazali \& Md. Sawari, 2014). There were some members of the community who have been confused with new perspectives and ideas highlighted by this movement. Among them were those who were prone to believe or almost believe it. There were also people who have similar belief and acted similarly with this movement but at the same time they did not agree with the thought of anti-Hadith. Hence, this study has been conducted to explore the measures need to be taken to eradicate this movement. This study also looked at the challenges encountered in this process.

\subsection{Research Objectives}

i. To identify the suitable measures to be proposed to various parties.

ii. To identify the problems arise from the influence of anti-Hadith movement. 


\section{Literature Review}

History has recorded that the thoughts of anti Hadith have evolved from the time of companions (Habeeb, 2006). However, with the wisdom of the companions, these movements have been abolished. The movements existed again in the 2nd century and have been solved successfully by Imam Shafie (Abdul Karim Ali 2007). According to Dr. Mustaffa alSibaci (1985), the first person to contend with this group was Imam Shafie who has written his intellectual arguements with one of the anti-Hadith members in his book al-Um. His lenghthy discussions on this matter were also written in his book, al-Risalah. Rejection of Prophet's tradition in the modern era began after Western colonization in Muslim countries, such as Iraq, Egypt, India and Pakistan. The colonizers have spread their beliefs and ideologies while colonizing these Islamic countries (Habeeb 2006). Among their teaching was the rejection of the teachings of Al-Qur'an and Sunnah. This was sufficient enough although in fact, what they really wanted was the rejection of Islam as a whole including Al-Qur'an and the Sunnah (al-Zahrani 1992). Many Muslim scholars especially those who went to study in Europe, have been affected and became their stooges or subordinates. Examples of famous Goldziher followers were Dr. Ali Hasan Abdul Kadir, Toha Hussin (1889-1973), Dr. Ahmad Amin (1886-1954), Rasyad Khalifa and Dr. Abu Rayyah. The Islamic scholars began to come forward to address on this issue in an effort to maintain the sanctity of Islam. Dr. Mustaffa alSibaci through his writing, al-Sunnah wa Makanatuha fi al-Tashric al-Islami was among the Islamic scholars who was involved in this global debate. He has stated in his book about the history of the rejection of Hadith and opinions expressed by the Sunni denials, besides answering those opinions. The second Islamic scholar who was involved in this interesting discussion was Dr. Muhammad Mustaffa al-Azomi in his book 'Dirasat fi al-Hadith al-Nabawi wa Tarikh Tadwinihi'. He began his superb writing with a definition of the Sunnah followed by the position of Sunni in Islam. Apart from that, he specifically discussed on the history of the rejection of the Sunnah in the past and in modern time. This book also entailed discussions on the history of writing Hadith, the study of Hadith Nabawi and debate about the isnad and the authenticity of the Hadith. The debate included the opinions from orientalists in matters regarding isnad and the authenticity of Hadith.

Islamic scholars in Malaysia were also interested to answer the misunderstanding caused by the anti-Hadith movements. After the publication of the book 'Hadis Satu Penilaian Semula' (Hadith A Reassessment) by Kasim Ahmad, the Islamic scholars in Malaysia have answered and criticized the book. Many books have been published in response to the book. Majlis Agama Islam Kelantan (MAIK, 1986) has published a book entitled 'Salah Faham Terhadap Hadis: Satu Penjelasan' (The Misunderstanding Of Hadith: An Explanation). The publication of this book aimed to explain the confusions and the views deviated with respect to the position of the hadith. This book entailed the aberrant thoughts of anti-Hadith, the origin of this thought which began from the orientalists, the position and importance of Hadith in Islamic tradition, an intentional confusion, how the companions accepted the Hadith and lastly, a collection of Hadiths in the time of companions. The next section concerned with the duty to obey the Sunnah as it is the teachings of Allah S.W.T and the Prophet S.A.W. The next section dealt with Sunnah as a source of aqidah and Islamic law followed by the discussion on the strength of Sunnah in terms of history and its alignment with the Qur'an and the reason. The next chapter discussed about the Sunnah as a foundation of faith and law followed by a call to return back to Al-Qur'an and Sunnah.

In 1987, Islamic Affairs Division (BAHEIS, 1987) of Prime Minister's Department has published a book titled 'The Status of Sunnah In Islamic Shariah'. This book has precisely explained on the authority of Sunnah besides including the history of repudiation of Sunnah in the past and present time. This book also included harsh thoughts towards hadith and the answers to these deviant beliefs.

Said Ibrahim (1987) during his mufti's position in Sabah has written a book entitled 'Penolakan Terhadap Penilaian Semula Hadis' (Rejection against Reassessment of the Hadith). In the beginning of his book, he put forward the four arguments agreed by Kassim Ahmad in upholding his ideas and criticized those arguments. The next section dealt with the rejection of allegations that the hadith contradicts the Quran. Shortly afterwards, he highlighted that the hadith is not deviant and debated with respect to the Hadith as the second source of Islamic legislation. In the end, he invited the readers to know the Prophet S.A.W and the discussion involved the division of Hadith, its history and the compilers of Hadith. Mahmud Zuhdi (1994) has compiled a book titled 'Beberapa Pemikiran Tentang litihad, Islah dan Tajdid' (Some Thoughts on ljtihad, Islah and Tajdid). This book was compiled together with a number of articles published by Dewan Budaya in 1986. The articles related to ijtihad, islah and tajdid were written by himself and many other writers such as Kassim Ahmad, Mahfodz Mohamad, S. Othman Kelantan and A. Ghani Ismail.

A book titled 'Anti hadis Jarum Yahudi' (Anti Hadith Yahudi's Needle) by Hj. Isa Ismail and Yusof Hj. Wanjor (1996) highlighted on the main pioneers of anti-Hadith movements including Goldziher, anti-Hadith movement in Egypt and United States. This book also stated about these movements' deviation as well as their interpretation of the Qur'an. On the other hand, Ustaz Hafiz Firdaus Abdullah (2002) has listed sceptical views of these groups and then answered them 
in his book '20 Hujah Golongan Anti hadis dan Jawapannya' (20 Arguments of anti-Hadith groups and the Answers).

Habeeb Rahman Ibramsa (2005) in his paper 'Pemikiran Anti hadis dan Perkembangan Semasa' (The Thoughts of anti-Hadith and their Current Developments), he included early history of the emergence of anti-Hadith movements which started during the period of the companions and the period of Imam Syafie. Then he continued with the development of anti-Hadith movement that began in the 19th century triggered by Western orientalists and their initiator was Goldziher. $\mathrm{He}$ also listed the pioneers and founders of anti-Hadith movements who were among Muslim community. Among the famous pioneers of these movements was Dr. Rashad Khalifa who has influenced Dr. Kassim Ahmad until the establishment of these movements in Malaysia.

Najah Nadiah (2005) in her paper 'Diayah Anti hadis Dalam Internet' (The anti-Hadith Propaganda through Internet) has revealed two websites which have been used by these anti-Hadith movements to spread their propagandas. The web site address is www.e-bacaan.com and www.stormloader.com/qsmjgm. These pages have appeared after the controvercial book, 'Hadis: Satu Penilaian Semula' (Hadith: A Reassessment) was banned and a nearly formed association named the Jemaah Al-Qur'an Malaysia (JAM) cannot be registered because of disapproval by the Islamic Center and Majlis Agama Islam Negeri nationwide. Within the website, there were principles of their beliefs, bibliography of the founders and topics such as politics, economy, science, religion, criticism, philosophy and general issues. Among the important matters in that website was their propagandas. They have presented their views based on Quranic translation of their own version. Another way of spreading their teachings was through the internet by e-mail and egroups. This two-way interaction facilitated their influences on those who possessed little knowledge of Islam and have weak faith.

Deden Suparman (2003) in his masters' thesis entitled 'Anti hadis Dan Ingkar Sunah: Suatu Kajian Perbandingan Antara Malaysia dan Indonesia '(Anti Hadith and Defiant Sunnah: A Comparative Study Between Malaysia and Indonesia) has conducted a research on anti-Hadith groups in both countries, answered the questions posed by them, explained the differences between the literal and technical meanings of Hadith, explained the relationship between the Qur'an and the Hadith, the levels of Hadith, exposed and corrected the beliefs of anti-Hadith groups and made comparisons between the anti-Hadith groups in Malaysia and Indonesia. He has stated nine confusing opinions caused by the anti-Hadith movements along with the answers. All the confusions engendered have been confirmed by their prominent figures such as Kassim Ahmad and Othman Ali through a separate interview sessions with both of them. He used questionnaire instrument for his data collection method and distributed it to 100 people in Malaysia and Indonesia. A total of ten questions related to the position of the Hadith were submitted to be answered by the respondents. The findings have shown that all respondents (100\%) acknowledged that Hadith is one of the source in Islamic law and reasoning in Islam. Even those who have the lowest level of faith and knowledge in Islam have supported this opinion and believed that Hadith is included in Islamic law. His study also revealed that the common view of Muslim society about anti-Hadith movements was that they (the anti-Hadith supporters) were those who did not understand Islam and those who rejected Hadith were at the same time rejected the Prophet S.A.W and the Qur'an.

Azmil Zainal Abidin (2005) in his paper 'Pengeliruan Orientalis Terhadap Aspek Periwayatan Dan Sanad Hadis: Reaksi Usul-Din' (The Orientalist's Obfuscation on the Aspect of Narration of Hadith and Its Sanad: Usul-Din Response) has stated sceptical views presented by the anti Hadith groups in relation to the cause of their rejection towards authentic Hadith. He also mentioned the answers of these views.

According to Fauzi Deraman (Ishak et al. 2007) in an article entitled 'Autoriti Hadis dan Penjelasannya' (The Authority of Hadith and Its Clarification) has touched upon the initial confusion of Hadith arised from an individual viewpoint. He expressed his arguement that the anti-Hadith movements which began in the modern era were initiated by the Orientalists followed by their followers among the Muslims. In Malaysia, the anti-Hadith groups have began their movements through the emergence of book of 'Hadis: Satu Penilaian Semula' (Hadith: A Reassessment) by Kassim Ahmad. The local Islamic scholars have published many books to answer the confusions.

Abdul Karim Ali (Ishak et al., 2007) in an article entitled 'Metode Imam Shafie Dan Ulama di Malaysia Dalam Menangani Golongan Yang Mempertikaikan Hadis: Satu Perbandingan '(Method of Imam Shafie And Islamic Scholars in Malaysia in Dealing with anti-Hadith Group: A Comparison), began his writing on the background of those who dispute the Hadith and Imam Shafie's approach in handling this issue. Besides that, he stated about those who rejected Hadith in Malaysia and their polemic against the hadith. He also listed the books written by anti-Hadith movements as well as the books of Islamic scholars in Malaysia who have answered the anti-Hadith's thought. Finally, he discussed on the comparative approach used by Imam Shafie and Islamic scholars in Malaysia in addressing this issue. 


\section{Research Methodology}

This research used a quantitative research method. The researchers used two methods for data collections which were library research and interview.

\subsection{Library Research}

This method has been used in the study to find out the information related to the definition of anti-Hadith, history of antiHadith in the past and modern period, their teachings, methodology used by them and so on. The materials for this study were books, newspapers, magazines, journals, working papers and so on. Library research also involved the Internet, which has become a major and important tool for anti-Hadith movements to spread their beliefs.

\subsection{Interview}

This method is used by interviewing individuals or certain parties including those who have already participated in the events organized by the anti-Hadith groups. Interviews were also conducted on some religious leaders and representatives of religion department at federal and state levels on the issue of anti-Hadith.

\section{Findings and Discussion}

\subsection{Actions by Authorities and Communities}

There have been many actions taken by the authorities, especially religious authorities whether at central or state level in addressing the issue related to anti-Hadith. Besides that, drastic actions were taken by the local educational institutions and individuals who were concerned about this issue in cooperation to prevent the misunderstanding from spreading.

\subsubsection{NGOs and Community's Action}

Non-governmental organizations (NGOs), especially with Islamic background have played a remarkable role by hindering the spread of this teaching beliefs and thoughts. In addition to the authorities and non-governmental bodies, there are also individuals who were involved in solving the issue related to anti-Hadith ideology.

\subsubsection{Complaint}

Actions that have been made so far by the authorities were based on complaints made by the public. Without their complaints, the authorities certainly will not be able to carry out their works properly.

\subsubsection{Writing}

In 1991, a book titled 'Islam dan Hadis: Satu Analisis Ke atas Usaha-Usaha Merosakkan Peribadi Dan Autoriti Rasullullah S.A.W.' (Islam and Hadith: An Analysis of Efforts to Ruin Personality and Authority of the Prophet s.a.w) has been published by a panel of ABIM chaired by Dr. Abdul Halim El-Muhammady. This book specifically addressed the issues raised by Kasim Ahmad in his book 'Hadis Satu Penilaian Semula' (Hadith A Reassessment). Amnah Bahari in her master's thesis entitled 'Critical Analysis of Kassim Ahmad's Controversial Issues on Hadis in Hadis Satu Penilaian Semula' has answered in specific with regards to Kassim Ahmad's writing. Besides that, Zulkifli Mohd through his master's thesis 'Anti-Sunnah Movement and its Impact on the Muslim Ummah' stated the opinions of Rashad Khalifa and Kassim Ahmad in relation to Hadith and their impact on the Islamic community. Mohd Hafiz Firdaus Abdullah has written a book entitled '20 Hujjah Golongan Anti hadis Dan Jawapannya' (20 Arguments of Anti-Hadith Movement and the Answers) in 2002 published by Perniagaan Jahabersa.

\subsubsection{Exposure in Newspaper}

Project Coordinator of Malaysian Muslim Consumers Association (PPIM), Noor Nirwandy Mat Nordin, has revealed through Harian Metro in January 17, 2006 about the existence of the anti-Hadith groups which aimed to spread beliefs, 
practices and thoughts based on al-Qur'an alone. He said that his team has found out about the activities of anti-Hadith groups on the Internet which can affect younger generation negatively.

\subsection{Actions by Governments}

At federal level such as JAKIM and state level like departments of religion have taken various measures to solve the issue from spreading.

\subsubsection{Fatwas}

On June 19, 1986, The National Fatwa Committee has examined in details on the book 'Hadis Satu Penilaian Semula' (Hadith A Reassessment) and concluded that the book is against the teachings of Islam and those who rejected the Hadith as a source of law is excluded from the teachings of Islam. The Committees have also recommended to the Ministry of Home Affairs for the book to be banned (BAHEIS, 1995). The National Fatwa Committee has made decisions in relation to the anti-Hadith on June 9, 1995 that:

i. Any person or group of people who adhere to the doctrines and ideologies comprised in the book 'Hadis Satu Penilaian Semula' (Hadith A Reassessment), 'Hadis Jawapan Kepada Pengkritik' (Hadith Answers to Critics), 'Pendedahan Kebenaran Adalah dari Tuhanmu' (Disclosure of Truth from Your Lord), 'Hadis di dalam AlQur'an' (Hadith in The Qur'an), 'Bacaan' (Reading), 'The Computer Speaks: God's Message To The World' or 'Risalah Iqra' 'is apostasy.

ii. Any Muslim is forbidden to teach, learn, practice, adhere to or spread the teachings and ideologies contained in the book 'Hadis Satu Penilaian Semula' (Hadith A Reassessment), 'Hadis Jawapan Kepada Pengkritik' (Hadith Answers to Critics), 'Pendedahan Kebenaran Adalah dari Tuhanmu' (Disclosure of Truth from Your Lord), 'Hadis di dalam Al-Qur'an' (Hadith in The Qur'an), 'Bacaan' (Reading), 'The Computer Speaks: God's Message To The World' or 'Risalah Iqra'. ${ }^{1}$ Mufti Office of Federal Territories through the Administration of Islamic Law (Federal Territories) Act 1993 under section 34 dated January 15, 1996 has issued fatwas and the contents were as follow: Any person or group of people who adhere to the teachings, beliefs or ideologies contained in the book or leaflets, the contents and translations, referred to subparagraph (A) are misguided as it contradicts the Islamic faith, morality and Shariah. ${ }^{2}$ Religious authorities in all states in Malaysia also advocated and proclaimed the apostasy of anti-Hadith movement brought by Kassim Ahmad. The following lists are the states in Malaysia with the dates and number of fatwas proclaimed in respect to the prohibition of anti-Hadith teachings. On March 28, 1991, the Legislative Committees of Selangor Islamic Religious Council (Majlis Agama Islam Selangor) has advocated that the teaching of $\mathrm{Hj}$. Khahar as wrong. The fatwa was proclaimed on August, 29, 1991 (JAKIM, 2005).

\subsubsection{The Prohibition of Books and and Organizations}

On June 7, 1986, the Ministry of Home Affairs has officially prohibited the book 'Hadith Satu Penilaian Semula' (Hadith A Reassessment) as recommended by the National Fatwa Committee (BAHEIS, 1995). Mufti Office of Federal Territories through the Administration of Islamic Law (Federal Territories) Act 1993, under section 34, dated on January 15, 1996 has issued this fatwa.

\subsubsection{Banned anti-Hadith Group Book}

i. The books of 'Hadith Satu Penilaian Semula' (Hadith A Reassessment) and 'Hadis Jawapan Kepada Pengkritik' (Hadith Answers to Critics) written by Kassim Ahmad and their contents;

ii. The book of 'Pendedahan Kebenaran Adalah Dari Tuhanmu- Hadis dalam Al-Qur'an' (Disclosure of Truth from Your Lord-Hadith in the Quran) written by Idris Abdul Rahman and its contents;

iii. The book of 'Bacaan' (Reading) written by Othman Ali and its contents;

iv. The book of 'The Computer Speaks- God's Message to the World' written by Dr. Rashad Khalifa and its

1 JAKIM Minute Meeting, prepared by Abdul Hamid b. Yunos.

2 The Administration of Islamic Law (Federal Territories) ACT 1993, Fatwa under section 34, dated on January 15, 1996, (JAWI/A/145;PN.(PU2) 530) 
contents;

v. The risalah of 'Igra' published by Jemaah Al-Qur'an Malaysia and its contents;

vi. Any translation of the book or risalah referred in item (i) to (v) and its contents in any language which contains the teachings, doctrines and beliefs that are contrary to Islamic beliefs and Shariah, confuses Muslims and leads to apostasy, is banned. ${ }^{3}$

The Legislation Committees of Selangor Islamic Religious Council on March 28, 1991 has banned a book written by Hj. Khahar which entitled 'Al-Furqan Pembeda' (al-Furqan a Differentiator) from being printed, distributed, sold, read, stored and used by the public (JAKIM, 2005). Kassim Ahmad has tried to register an organization, Jemaah Al-Qur'an Malaysia legally but did not get approval from the government on August 25, 1998. ${ }^{4}$

\subsubsection{Dialogue Session}

Selangor Islamic Religious Department (JAIS) had several discussions with $\mathrm{Hj}$. Abdul Kahar and some of his followers in 1990, including two formal discussions chaired by S.S. State Mufti. JAIS also had an event, 'Majlis Penjelasan Akidah' (Akidah Explanation Event) to the followers of this movement on 24 February 1998 in cooperation with JAKIM and some local people. A meeting has been held between the Research Division of JAKIM and $\mathrm{Hj}$. Khahar together with his followers on March 15, 1998 at Haji Khahar's home in Kg. Kemesah, Hulu Kelang (JAKIM, 2005).

\subsubsection{Legal Actions}

On 8 April 1991, Hj. Khahar and six of his followers have been charged under Section 150 of Selangor Islamic Religious Administration Act as an offence of not performing Friday prayer and fined for RM 300 or two months imprisonment. Again in 2002, JAIS tried to take actions against him for the same offense. However, this case could not be not proceed due to technical reasons. On June 23, 2003, Hj. Khahar was arrested for his Prophethood allegation. The first charge was read in Gombak Syariah Court on June 23, 2005 and subsequently transferred to Shah Alam Syariah High Court under Section 8 (False Accusation) Syariah Criminal Enactment of Selangor State 1995 (JAKIM, 2005).

\subsubsection{Publication}

In 1986, Kelantan Islamic Religious Council (MAIK) published a book entitled 'Salah Faham Terhadap Hadis' (The Misunderstanding Of Hadith) written by Hj. Ismail Hj. Yusof. On August 25 in the same year, Former Students of Middle East Association launched a book titled 'Penjelasan Mengenai Hadis Dan Kod 19' (Explanation about Hadith and Code 19) written by Dr. Mahayudin Hj. Yahya, Dr. Huda Mohsen and Dr. Fatah Haron. Haji Said Ibrahim wrote a book entitled 'Penolakan Terhadap Penilaian Semula Hadis' (Objection Against Reassessment of Hadith) in 1987 published by Media Hasda. Faculty of Islamic Studies published a book entitled 'Jawapan Kepada Buku Hadis Satu Penilaian Semula' (The Answer to Hadith a Reassessment Book) written by Dr. Harun Din and his colleagues in 1988. In 1995, the Islamic Affairs Division of Prime Minister's Department published a book titled 'Penjelasan Terhadap Fahaman Anti Hadis' (Explanations towards Anti-Hadith Ideologies). Research Division of Federal Territory Religious Department has issued a list of heresy movements since 1997-2004 which entailed the name of the movements, their founders, areas, characteristics of the offense, fatwas' date and gazette.

\subsubsection{Dissemination of Leaflet (Risalah)}

Religious authorities took actions by disseminating free leaflets to public in order to inform and give awareness publicly on the danger of heresy movements. For example, leaflets issued by Selangor Islamic Religious Department (JAIS) in July 2006 entitled 'Tips-tips Mengenali Ajaran Menyeleweng' (Information on How to Recognize Heresy Movements). These leaflets have listed about 31 methods to recognize whether the teaching could be accepted or not (JAIS, 2006). Leaflets regarding teaching, understanding and tarikat that have been gazetted were issued by JAWI to give awareness to society about the presence of heresy groups in Malaysia. ${ }^{5}$

\footnotetext{
3 The Administration of Islamic Law (Federal Territories) Act 1993, Fatwa under section 34, dated on January 15, 1996, (JAWI/A/145;PN.(PU2) 530)

4JAKIM Minute Meeting, prepared by Abdul Hamid b. Yunos.

${ }^{5}$ Leaflets regarding teaching, understanding and tarikat that have been gazetted since 1997-2004.
} 


\subsubsection{Disposure in Newspaper}

Kosmo daily newspaper on Thursday, May 18, 2006 has listed 23 types of heresies in Selangor. It also quoted opinions from Mufti of Selangor regarding those who were influenced and become followers of heresy movement. Those followers were not only people with lack of Islamic knowledge but also professionals in religion.

\subsection{Obstacles in Dealing with anti-Hadith Movement}

In fact, the authorities failed to eliminate anti-Hadith movements and their ideologies as a whole. This failure was due to some obstacles that hindered such efforts. They were as follow.

\subsubsection{Intellectual Group}

Individuals who became proponents of anti-Hadith movements were not the old-fashioned villagers or typical people in community as what most people believed they were. Instead, they were intellectuals with higher educational background such as university lecturer, journalist, author, writer, medical practitioner, doctor of philosophy in economics and so on (JAKIM t.th.). It can be proven based on the educational background of the founder, Dr. Kasim Ahmad.

Religious authorities were somewhat threatened when dealing with their arguments. Therefore, the authorities have made good preparations to face with these groups through local experts who could argue with them. Apart from that, people were easily influenced by intellectuals and those who were good in giving their opinions as well as arranging their words. The facts that were quite logical in thinking were easily accepted by people without arguing and asking further opinions from the others.

\subsubsection{Supports from Influential Group}

A group cannot be eliminated wholly until to its root when they were supported by influential elites. Enforcements from authorities could not continue and they became non-transparent. Actions were taken only on few individuals who became 'blacksheep' to cover the errors made by influential individuals. Furthermore, the anti-Hadith groups have a close relationship with those who have influence and power (JAKIM t.th.). This has been agreed by Kassim Ahmad in his opening speech during the fifth annual gathering of JAM on June 17, 2000 in the meeting room 1, Hotel 1926, Jalan Burma, Penang. Kasim Ahmad said: "In the meantime, we must know the factor that favor us. We should be grateful to the Prime Minister, Dr. Mahathir Mohamad, as he has not only agreed with our ideologies and talk in various forums related to it, but also has saved some of us from being arrested under ISA! The thing that I know for sure". ${ }^{6}$

\subsubsection{Secret Movement}

After have been banned by the government, the anti-Hadith movements engaged in secret to prevent from being detected by the authorities. Their secret movements gave difficulties to the authorities to trace them as well as take actions against them. The researcher has met a young man who has already participated in several meetings that have been arranged. According to him, they met in small groups which location was always changed. Students were not allowed to know who their teachers were. Their meeting sessions were based on certain stages including; the introduction stage, the stage of repentance and the level of emigration. One of the lessons that took place in each session was the interpretation of the Qur'an. To reach the level of repentance, the students have to pay certain amount to their teachers. It was also similar to achieve the level of emigration in which they were asked to engage in jihad by paying huge sums of money to their teachers to migrate to a Muslim country. Based on anti-Hadith beliefs, there was only one Muslim country in the world and the youth has not stated its name.

\subsubsection{Absence of Report}

Religious authorities like JAKIM, JAWI, JAIS and so on required reports from the public to act. Based on the reports, they will begin the investigation and seek for evidences as proofs of authenticity of the reports. They will act in accordance with existing legal procedures only after proving the existence of the anti-Hadith groups or individuals. The actions from

${ }^{6}$ Kassim Ahmad, Jun 2000, Opening Speech and Chairman Report on the fifth Annual Meeting. 
the authorities could not be implemented in the absence of reports from the public. It has given a lot of advantages to anti-Hadith groups to continue their ideologies and further develop their understanding without further hindrance.

\subsubsection{Limited Power of Authorities}

Since colonial era, the distribution of power has been divided into two parts; the first part is the Prime Minister who holds executive power in the administration of state and the second one is the King who has power in the matter of religion and tradition. According to this division, religious authorities also has became limited in power. Religious authority with Shariah Court as its highest institution only has the power regarding the issues of marriage, divorce, child custody, inheritance, matrimonial property, zakat, waqf, close proximity or khalwat and ibadah. Other problems such as murder, theft, robbery, rape, adultery, corruption, abuse of power and others were under the jurisdiction of Civil Court. Shariah Court was not only limited in terms of power. Instead, it was also limited in terms of punishment to be imposed to the offenders. Penalties which were commonly used as in today such as fines and imprisonment were limited to certain amount and duration. Shariah Court judge could not impose a more severe punishment than the maximum sentence. For example, the Enactment of the Shariah Criminal Law (Selangor) 1995. Among the offenses that might be imposed under the jurisdiction of Shariah Court were the act of incest under section 22, prostitution under section 23, adultery under section 25 and preparing for adultery under section 26 . The conviction of these offenses will be penalised with legal fine of not more than RM 5000 or not more than three years imprisonment or not more than six lashes or any combination of these penalties. ${ }^{7}$

\subsubsection{Lack of Knowledge on anti-Hadith Movement}

Lack of knowledge among Muslim community about the existence of anti-Hadith movements (what is the anti-Hadith movements and who are they? ) also became a major obstacle to stop this heresy movement. Their ignorance about these movements were due to their ignorance about Islam. If they did not know the truth, how they could identify the false? They were easily influenced by these movements in the state of ignorance as they came with simple and interesting teachings. Such people, even if they were not affected, were still not helpful in solving this heresy ideology.

\section{Concluding Remarks}

The anti-Hadith groups have existed in Malaysia since 1984. These groups were led by intellectuals and supported by influential people. They have moved secretly after being banned and participated with other similar ideologies which were against the Islamic teachings and law. They continued to spread in various ways and using all the opportunities that they have. No action could be taken against them due to the absence of reports from the public and consequently, evidences about their existence were very difficult to obtain. The use of internet helped them in spreading their ideologies without being detected easily by the authorities. People who have no basic knowledge about Islam were easily influenced by their beliefs. Besides that, those who have already engaged in the anti-Hadith teachings will not be reprimanded or advised by anyone and he himself did not ask anyone. This phenomenon will eventually help the anti-Hadith movements and must be solved immediately. Therefore, a further study is needed to investigate the extent to which anti-Hadith ideologies have influenced and affected communities. The findings of this study are useful for all especially the religious authorities to regulate measures and strategies in facing this issue.

\section{References}

al-Sibaci, Mustaffa al-Sibaci. 1405H/1985. al-Sunnah wa makanatuha fi al-tasric al-islami. Ed. ke-4. Beirut: al-Maktab al-Islami. al-Zahrani, Muhammad ibn Matr. 1412H/1992. Tadwin al-sunnah al-nabawiyyiah.

Ed.baru. Taif: Maktabah al-Siddiq.

Baheis, Bahagian Hal-Ehwal Agama Islam. 1987. Kedudukan sunnah dalam Islam. Ed. baru. Kuala Lumpur: Jabatan Perdana Menteri. Deden Suparman. 2003. Anti Hadis Dan engkar sunnah: suatu kajian perbandingan antara Malaysia dan Indonesia. Tesis Sarjana Usuluddin, Jabatan Sejarah Dan Tamadun Islam, Akademi Pengajian Islam, UM.

Habeeb Rahman Ibramsa. 2004. Pemikiran Antihadis Dan Perkembangan Semasa.

Kertas kerja Seminar Hadis: Cabaran Dan Masa Depan. Anjuran UKM dan KUIS. Bangi, Selangor, 13 Mac.

Hafiz Firdaus Abdullah. 2002. 20 Hujah golongan antihadis dan jawapan. Johor Bahru: Perniagaan Jahabersa.

${ }^{7}$ See: Enactment of the Shariah Criminal Law (Selangor) 1995. 
Ishak Hj. Sulaiman, Fauzi Deraman, Mohd. Muhiden Abd. Rahman \& Abdul Karim Ali. 2007. Autoriti hadis menangani gerakan antihadis. Ed. baru. Kuala Lumpur: Universiti Malaya.

Mahmud Zuhdi (pnys.). 1994. Beberapa pemikiran tentang ijtihad, islah dan tajdid. Kuala Lumpur: Dewan Bahasa dan Pustaka. Maik, Majlis Agama Islam Kelantan. 1986. Salah faham terhadap hadis: satu penjelasan. Ed. baru. Kota Bharu: Maik.

Said Ibrahim. 1987. Penolakan terhadap penilaian semula hadis. Ed. baru. kuala Lumpur: Media Hasna.

Ghazali, M. A., Md. Sawari, S. S., (2014). The Influence of anti Hadith Group (GAH) Thinking on the Muslim Ummah: A Special Study in the Klang Valley. Al-Bayan: Journal of Qur'an an Hadith Studies 12 (1), 75-86, 17 July 2014, Retrieved from http://books andjournals.brillonline.com/content/journals/22321969/12/1

Wilayah Persekutuan. 1996. Akta Pentadbiran Undang-Undang Islam (Wilayah-

Wilayah Persekutuan) 1993. Fatwa di bawah seksyen 34. (JAWI/A/145;PN.(PU2) 53 0). 